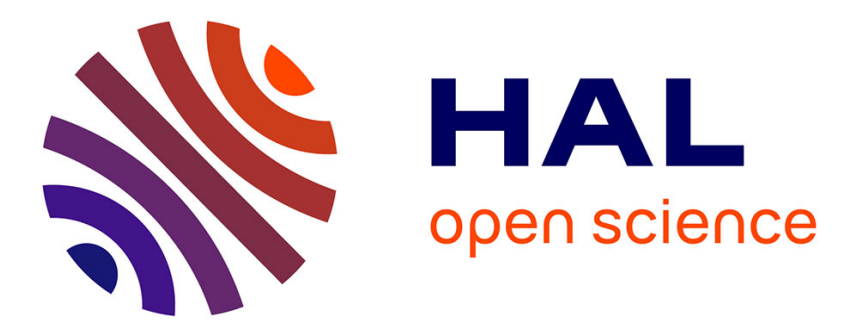

\title{
SPATIAL EXTERNALITIES, RELATEDNESS AND SECTOR EMPLOYMENT GROWTH IN GREAT BRITAIN
}

Paul Bishop, Peter Gripaios

\section{> To cite this version:}

Paul Bishop, Peter Gripaios. SPATIAL EXTERNALITIES, RELATEDNESS AND SECTOR EMPLOYMENT GROWTH IN GREAT BRITAIN. Regional Studies, 2010, 44 (04), pp.443-454. 10.1080/00343400802508810 . hal-00588364

\section{HAL Id: hal-00588364 https://hal.science/hal-00588364}

Submitted on 23 Apr 2011

HAL is a multi-disciplinary open access archive for the deposit and dissemination of scientific research documents, whether they are published or not. The documents may come from teaching and research institutions in France or abroad, or from public or private research centers.
L'archive ouverte pluridisciplinaire HAL, est destinée au dépôt et à la diffusion de documents scientifiques de niveau recherche, publiés ou non, émanant des établissements d'enseignement et de recherche français ou étrangers, des laboratoires publics ou privés. 


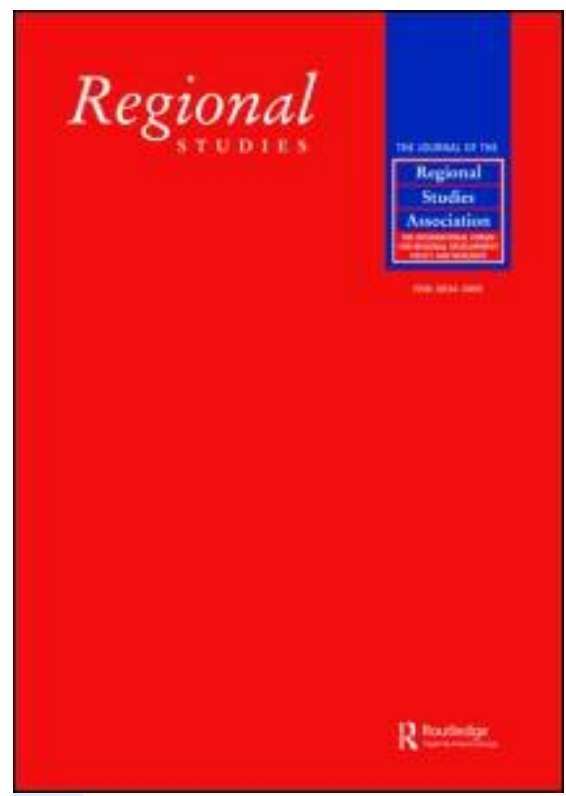

SPATIAL EXTERNALITIES, RELATEDNESS AND SECTOR EMPLOYMENT GROWTH IN GREAT BRITAIN

\begin{tabular}{|r|l|}
\hline Journal: & Regional Studies \\
\hline Manuscript ID: & CRES-2007-0166.R2 \\
\hline Manuscript Type: & Main Section \\
\hline JEL codes: & $\begin{array}{l}\text { R11 - Regional Economic Activity: Growth, Development, and } \\
\text { Changes < R1 - General Regional Economics < R - Urban, Rural, } \\
\text { and Regional Economics, R12 - Size and Spatial Distributions of } \\
\text { Regional Economic Activity < R1 - General Regional Economics < R } \\
\text { - Urban, Rural, and Regional Economics }\end{array}$ \\
\hline Keywords: & Spatial Externalities, Employment Growth, Great Britain \\
\hline
\end{tabular}

\section{(s) ScholarONE" \\ Manuscript Central}




\title{
SPATIAL EXTERNALITIES, RELATEDNESS AND SECTOR EMPLOYMENT GROWTH IN GREAT BRITAIN
}

\author{
Paul Bishop \\ Peter Gripaios
}

Dr Paul Bishop and Professor Peter Gripaios are in the Plymouth Business School, University of Plymouth, Drake Circus, Plymouth, Devon PL4 8AA.

E-mail: paul.bishop@plymouth.ac.uk; peter.gripaios@plymouth.ac.uk

First received: June 2007

Accepted: June 2008

Correspondence to:

Dr Paul Bishop

Reader in Economics,

Plymouth Business School,

University of Plymouth

Drake Circus

Plymouth

Devon

PL4 8AA 


\title{
SPATIAL EXTERNALITIES, RELATEDNESS AND SECTOR EMPLOYMENT GROWTH IN GREAT BRITAIN
}

\begin{abstract}
This paper examines the impact of externalities on employment growth in sub-regions of Great Britain by estimating OLS and maximum likelihood spatial models at the 2-digit level for 23 sectors. Issues arising from relatedness, sector differences, competition, cross-boundary spillovers and spatial autocorrelation are explicitly addressed. Results indicate that specialisation has a generally negative impact on growth whilst the impact of diversity is heterogeneous across sectors and strong local competition has a typically positive impact. The results question the merits of policies primarily aimed at promoting regional specialisation and suggest that diversity, local competition and sector heterogeneity are important policy issues.
\end{abstract}

JEL classification: R11, R12.

Keywords: Spatial externalities, employment growth, Great Britain

Räumliche Externalitäten, Beziehungen und sektorales Beschäftigungswachstum in Großbritannien

Paul Bishop and Peter Gripaios

ABSTRACT

http://mc.manuscriptcentral.com/cres Email: regional.studies@newcastle.ac.uk 
In diesem Beitrag untersuchen wir die Auswirkung von Externalitäten auf das Beschäftigungswachstum in den Subregionen von Großbritannien mit Hilfe einer OLSSchätzung und räumlicher maximaler Wahrscheinlichkeitsmodelle auf zweistelliger Ebene für 23 Sektoren. Insbesondere gehen wir auf Aspekte der Bereiche Beziehung, Sektorunterschiede, Wettbewerb, grenzüberschreitende Übertragungen und räumliche Autokorrelation ein. Die Ergebnisse weisen darauf hin, dass sich eine Spezialisierung generell negativ auf das Wachstum auswirkt, während die Auswirkung von Vielfalt innerhalb der Sektoren heterogen ausfällt und ein starker lokaler Wettbewerb in der Regel positive Auswirkungen hat. Die Ergebnisse stellen den Nutzen von Politiken in Frage, die in erster Linie auf eine Förderung der regionalen Spezialisierung abzielen, und legen den Schluss nahe, dass Vielfalt, lokaler Wettbewerb und Sektor-Heterogenität wichtige politische Aspekte darstellen.

JEL classification: R11, R12.

Keywords:

Räumliche Externalitäten

Beschäftigungswachstum

Großbritannien

Efectos externos espaciales, relaciones y el crecimiento sectorial del empleo en Gran Bretaña

\section{Paul Bishop and Peter Gripaios ABSTRACT}

En este artículo examinamos los efectos de factores externos en el crecimiento de empleo en las subregiones de Gran Bretaña calculando los MCO (mínimos cuadrados ordinarios) y los modelos espaciales de la probabilidad máxima a un nivel de 2 dígitos para 23 sectores. Aquí analizamos específicamente las relaciones, las diferencias entre sectores, la competencia, los desbordamientos transfronterizos y la autocorrelación espacial. Los resultados indican que en general la especialización tiene un impacto negativo en el crecimiento mientras que el impacto de la diversidad es heterogéneo en todos los sectores y una fuerte competencia local tiene un impacto típicamente positivo. Los resultados cuestionan los méritos de las políticas destinadas principalmente a fomentar la especialización regional e indican que la diversidad, la competencia local y la heterogeneidad sectorial son aspectos políticos importantes.

Keywords:

Factores externos espaciales

Crecimiento del empleo

Gran Bretaña

JEL classification: R11, R12. 


\title{
INTRODUCTION
}

Policy makers have made the development of "clusters" of economic activity a central element of regional policy in recent years (BRYAN et al, 2005; CUMBERS AND MACKINNON, 2004). This renewed interest in the benefits of local specialisation has been associated with the work of PORTER (1998, 2000), although arguments supporting the benefits of local agglomerations can be traced back to MARSHALL (1890). However, these policy developments have tended to undervalue the potential benefits of a diverse industrial base, including the promotion of economic stability and the facilitation of external economies which operate across industrial sectors (FRENKEN et al, 2007). Indeed, there is a considerable academic debate as to whether specialisation or diversity is most conducive to local growth (CINGANO AND SCHIVARDI, 2004). This debate has been given added stimulus by a resurgence of interest in growth theory and the central importance of knowledge spillovers to many modern theories (FRENKEN et al, 2007). There is a strong geographical dimension to this recent literature, reflecting the widespread view that knowledge spillovers are often highly localised as they are difficult to codify and may be best promoted through face to face contact (VAN STEL AND NIEUWENHUIJESEN, 2004).

\begin{abstract}
A substantial empirical literature assessing the importance of externalities to local growth has developed building on original contributions from GLAESER et al (1992) and HENDERSON et al (1995). However, most of this literature has measured diversity in terms of a single measure reflecting average diversity across an entire local economy.
\end{abstract}

http://mc.manuscriptcentral.com/cres $\underset{4}{4}$ mail: regional.studies@newcastle.ac.uk 
This neglects the fact that spillovers might be best promoted when there is a degree of relatedness between relatively distinct sectors in terms of, for example, products, knowledge-base, technology or skills. In addition, whilst many early studies concentrated on the manufacturing sector, it has been increasingly recognised that the potential to benefit from spillovers may differ across industrial sectors (DEIDDA et al, 2006). A further issue is the existence of spillover effects across local boundaries which may give rise to spatial autocorrelation (VAN OORT, 2007, DEIDDA et al, 2006). This is particularly relevant given that regional units typically have boundaries that are administrative in nature rather than a reflection of geographical areas that have strong economic coherence.

This paper explicitly examines the issues of relatedness, sector differences and crossboundary spillovers within the context of an empirical study of 2-digit industries across sub-regions of Great Britain. Although there have been several European sector studies in recent years, there has been no detailed study utilising data at this level for Great Britain. Moreover, existing sector studies have typically incorporated measures of overall diversity in their empirical work rather than distinguishing between related and unrelated diversity. Recent studies by COMBES (2000) and DEIDDA et al (2006), for example, measure diversity in terms of the inverse of the Herfindahl index and do not include related diversity. Thus, the study presented in this paper is novel both in terms of the data utilised and the consideration of the issue of relatedness at the sector level. In addition, the conclusions provides some interesting contrasts (and some confirmation) of existing empirical studies. 
The paper begins with an overview of the theoretical arguments linking local growth to externalities, followed by a brief discussion of existing empirical evidence. The next section discusses the model used in the study, which is based on the GLAESER et al (1992) approach. The following section outlines the data and methodology, which incorporate both OLS and maximum likelihood techniques to take into account spatial autocorrelation. Finally, the conclusion examines the wider theoretical and policy-related issues arising from the paper.

\section{SPILLOVERS AND LOCAL ECONOMIC GROWTH}

Recent approaches to economic growth have emphasised the importance of knowledge spillovers (ROMER 1986). Such spillovers may foster growth if innovations and improvements in one organisation yield external benefits to other firms without the beneficiary paying full compensation (GLAESER et al, 1992). An important distinction is often made between dynamic knowledge externalities, which reflect the role of prior information accumulations on growth, and static externalities (such as economies arising from the co-location of firms in an industry close to major suppliers), which influence overall spatial patterns of location (HENDERSON et al, 1995). As dynamic externalities are fostered by a history of interactions and long-term relationships, spatial proximity may play a critical role in facilitating the transmission of these effects (VAN STEL AND NIEUWENHUIJESEN, 2004). However, whilst there is considerable agreement that such externalities are important, there are conflicting views as to the type of spillover effects 
which are most beneficial. In particular, there is a debate as to whether spillovers occur mainly within industries (localisation economies), across industries (Jacobs externalities) or are associated with the overall size and population density of a local economy (urbanisation economies) (FRENKEN et al, 2007).

Much recent literature has distinguished three alternative theoretical approaches which generate hypotheses for the testing of the relative importance of spillover effects (VAN OORT, 2005). The first view, the Marshall-Arrow-Romer (MAR) approach, argues that knowledge is primarily sector specific and hence specialisation enhances growth as it facilitates these within-sector spillovers. This view also argues that local market power encourages growth as it facilitates the internalisation of the benefits from new knowledge. A second approach, associated with PORTER (1998, 2000), agrees that spillovers are primarily sector specific but argues that competition stimulates innovation and growth as firms are pressed to innovate to survive and prosper (PORTER, 1990). The third view, associated with JACOBS (1969), agrees with Porter that competition promotes growth, but also argues that diversity encourages growth as knowledge spillovers frequently occur across sectors. Indeed, such cross-sector spillovers may facilitate more radical innovations than those arising from within-sector spillovers which are likely to take the form of incremental changes to existing technologies (FRENKEN et al, 2007).

Whilst the three alternative approaches offer distinct hypotheses concerning the nature of spillovers and competitive effects, the dichotomy between specialisation and diversity 
risks oversimplifying a complex phenomenon. Some relatively distinct sectors may share some commonalities in terms of, for example, similar customers, technologies and knowledge-bases. If such commonalities foster spillovers, then the benefits gained by a particular sector may be influenced by the presence of related economic sectors rather than diversity per se (FRENKEN et al, 2007). In the corporate strategy literature, for example, it is frequently argued that related diversification is more profitable than unrelated diversification due to enhanced synergies and the ability to utilise core competences and surplus assets (including knowledge) more efficiently across related areas (BRUCHE, 2000). However, whilst the strategy literature focuses upon the benefits of spillovers across related activities within a firm, economic geography emphasises the importance of spillovers across firms within a specific location. Taken together, these arguments would suggest that both spatial proximity and relatedness contribute towards enhancing spillovers.

One complication in assessing the impact of spillovers arises from the possibility that different types of spillovers have differing impacts on local growth. FRENKEN et al (2007), for example, argue that related variety (a term they use in preference to related diversity) is likely to be positively associated with employment growth as such external effects often take the form of radical cross-sector innovations involving the creation of new products and technologies. Conversely, within-sector externalities are likely to lead to incremental improvements within a sector and may be positively related to productivity growth. As unrelated variety is less likely to generate spillover effects, it is unlikely to yield direct benefits in terms of employment or productivity growth although 
it may enhance stability and long term growth if it protects a local economy from sectorspecific demand shocks. These arguments are of some importance as most of the academic literature (including the present study) concentrates on employment growth and, consequently, might underestimate the importance of specialisation externalities and unrelated variety to regional growth and stability.

The concept of relatedness provides a useful basis for theorising about sector differences in spillover effects. For example, sectors operating with highly specialised technologies, may find it difficult to benefit from spillovers as there are few local sectors utilising similar technologies. Conversely, sectors operating on a more generic or diverse basis may find more opportunities to exploit spillovers (BISHOP AND GRIPAIOS, 2007). This argument might support the view that services and manufacturing sectors benefit disproportionately from diversity. COMBES (2000), for example, notes that many services are highly diversified in terms of the range of customers and inputs required and may benefit more from a diverse local economy than some manufacturing sectors that have a narrower customer and input base. Other differences might be related to different degrees of tradability across regional boundaries (DEIDDA et al, 2006). The demand for non-tradables (including many services), is limited by local demand and, consequently, there are limits to the extent to which a non-tradable sector can specialise and take advantage of localisation economies. However, tradables (much manufacturing industry) operate in more geographically diverse markets and are less constrained by the need to locate close to consumers. Such industries can become more concentrated to take advantage of specialisation externalities and economies of scale (KRUGMAN AND 
VENABLES, 1995). However, it is important to recognise that modern telecommunications systems have enabled the delivery of many services remotely by phone or the internet. This has enabled some services to concentrate in certain locations and potentially gain benefits from local specialisation.

Of course, just as the distinction between specialisation and diversity is oversimplified, the same criticism can be levelled at the distinction between manufacturing and services. These sectors are far from homogenous and the rise of new services associated with modern technologies may have further enhanced the heterogeneity of the sector. BLIEN AND SUEDEKUM (2005), for example, make a distinction between advanced services (e.g. consulting, higher education) and basic services (e.g. cleaning, domestic services). They argue that advanced services typically involve a variety of skilled professionals who may potentially generate significant spillovers through personal interactions. This is in contrast to less sophisticated services where the opportunity for significant developments through the interaction of such professionals is more limited. Other researchers utilise slightly different classification schemes to reflect the heterogeneity of services. VAN OORT (2007), for example, distinguishes industry (primarily manufacturing) from three types of services - distribution, personal and business services, whilst other studies (e.g. DEIDDA et al, 2006; COMBES, 2000) conduct analysis at the sector level, typically utilising 2-digit sectors. Given the multiplicity of factors potentially influencing the extent of spillovers, a disaggregated approach would seem to offer the best way forward for understanding these complex issues. 
A third type of spillover is possible if benefits arise from the size and density of a local economy and potentially benefit all firms regardless of their industry (ESSLETZBICHLER, 2005). These urbanisation economies (often conflated with Jacobs-externalities) may emerge from a variety of sources including a superior infrastructure, larger labour markets, universities, business networks and higher level government functions. Conversely, size may be associated with increased costs arising, for example, through increased congestion and this may offset any urbanisation economies. Given that the local units used in the empirical analysis of externalities are typically of varying size and density, it is essential to control for these effects in empirical analysis.

A final issue of some importance is the spatial extent of spillovers. Whilst it is reasonable to argue that proximity promotes spillover effects and knowledge externalities decline over distance (VAN OORT, 2007), it is not clear how to delineate the area over which spillover effects occur. Moreover, the spatial extent of spillovers may differ substantially across sectors. Given that the spatial units for which data are typically available are administrative units and are not defined with spillover effects in mind, there may be interdependencies across observations. Externalities that generate employment growth in one sub-region may impact on growth in adjacent regions leading to interdependence between employment growth in both regions. Thus, it may be of considerable importance (at least for some sectors) to take into account such dependencies through the use of spatial econometric techniques. 
In addition to spatial proximity, wider spatial effects may operate across broader regions. These may, for example, reflect the operation of regional labour markets, geography (e.g. peripherality), cultural effects and the influence of spatial regimes operating through regional policy organisations (VAN OORT, 2007). In the UK, for example, it has frequently been argued that a "north-south divide" has existed in growth rates (ROBERTS, 2004). This may be associated with skill differentials, the historical impact of industrial structure and geographical factors such as proximity to the capital city. Consequently, it is necessary to take into account the possibility of this broader spatial heterogeneity in any modelling.

\section{EMPIRICAL STUDIES}

Many empirical studies use variants of a model introduced by GLAESER et al (1992) in which employment growth is used as a proxy for performance. This study finds that employment growth is positively related to competition and diversity whilst specialisation reduces growth. These conclusions are interpreted as evidence in favour of the Jacobs approach. However, in a study of eight U.S. manufacturing industries, HENDERSON et al (1995) find evidence of both MAR and Jacobs-type externalities, with the latter only of relevance for new high technology industries. VAN OORT (2007) notes that some of the differences between these studies may be attributable to different data sources and industry samples, whilst COMBES (2000) has pointed to various methodological problems. Of more general concern is the use of employment growth as a 
proxy for performance. Given that externalities imply a change in output not fully accounted for by a change in inputs, total factor productivity (TFP) would be a better measure of performance. However, in most studies, the use of employment growth as the dependent variable is necessary as a lack of data on local sector output and capital stock preclude the measurement of TFP. This may lead to a number of problems in interpreting the results of empirical studies (DECKLE, 2002). In particular, externalities which have a beneficial impact on TFP do not necessarily yield proportionate increases in employment (CINGANO AND SCHIVARDI, 2004). For example, if a firm benefits from a positive productivity increase arising from an externality, employment may fall if the elasticity of demand is low (COMBES, MAGNAC AND ROBIN, 2004). Thus, whilst employment regressions provide an important insight into the employment implications of externalities, they do not necessarily provide a clear picture of the productivity impact. Despite these problems, policy makers are frequently concerned with employment creation as an objective and hence the emphasis on employment is of interest from a policy perspective, provided the caveats concerning the method are highlighted.

Whilst the number of studies utilising employment growth regressions has grown in recent years, the results are inconclusive. Many studies find that specialisation has a generally negative impact on growth, including those for France by COMBES (2000) and Italian studies by DEIDDA et al (2006) and PACI and USAI (2002). Conversely, a further Italian study by FORNI and PABA (2001) and a Dutch study by VAN SOEST et al (2006) find a positive impact. There are many studies that find a broadly positive impact for diversity (e.g. PACI and USAI, 2002; VAN OORT, 2007), although 
SHEARMUR and POLESE (2005) find no systematic long-term evidence of diversity externalities for Canada. As far as competition is concerned, data limitations often ensure that variables that proxy for competition are directly related to firm size and it is difficult to distinguish between the impact of competition and scale economies. However, in general terms, most studies find a positive impact for competition and/or a negative impact of firm size (e.g. VAN OORT, 2007; DEIDDA et al, 2006).

A small number of recent studies have used alternative measures of performance (e.g. CINGANO and SCHIVARDI, 2004; VAN STEL AND NIEUWENHUIJESEN, 2004) However, the results of these studies are far from consistent. Moreover, the studies typically use a higher level of aggregation than most employment based studies or rely upon restricted samples of firms or sectors (DEIDDA et al, 2006). Another strand of research has sought to focus attention upon differences across a few broad sectors (e.g. VAN OORT, 2007; BLIEN AND SUEDEKUM, 2005; VAN STEL AND NIEUWENHUIJESEN, 2004; DECKLE, 2002). The different sector breakdowns, methods used, performance measures and countries examined once again makes any consistent pattern of results difficult to ascertain. However, the results for manufacturing are reasonably consistent suggesting no evidence of positive specialisation externalities, whilst diversity has either a positive or insignificant impact on growth. There is no consistent pattern apparent for competition, whilst the sign and significance of the results for services differ widely across the various categories. 
The conflicting results of the broad sector studies suggest that a more disaggregated approach may be useful. COMBES (2000) examines 94 sectors in France and finds that that specialisation typically has a negative impact on employment growth in services and usually a negative or insignificant impact on industry. Diversity typically has a positive relationship on employment growth in services but a negative or insignificant impact on industry, whilst competition generally has a negative impact on growth across all sectors. However, there are a number of sectors which do not fit these patterns and the magnitude of the various effects differs, suggesting that whilst the industry/service distinction is useful, it masks some within-sector differences. This point is emphasised by an Italian study by DEIDDA et al (2006) which concludes that, whilst specialisation externalities are mostly negative for services and manufacturing, the magnitude of the effect is much greater for services. Moreover, whilst diversity externalities are positive for the aggregate economy as a whole they play a positive role in less than half of the individual sectors.

The importance of examining externalities at a disaggregated level is emphasised by studies which take into account spatial autocorrelation. DEIDDA et al (2006), for example, find spatial autocorrelation in 10 out of 34 sectors, whilst VAN OORT (2007), finds important differences across four broad sectors. In addition, a number of studies, including VAN OORT (2007) find that regional dummies representing broader spatial regime effects are linked to growth. Taken together, these results imply that spatial relationships across both contiguous and wider areas need to be included in the analysis of externalities but the importance of such effects may be sector specific. 
Most empirical studies define diversity in terms of a broad measure across the economy as a whole (e.g. the Herfindahl Index). However, the theoretical considerations outlined in the previous section suggest that the distinction between related and unrelated variety may be important. Several recent studies confirm this. FRENKEN et al (2007), for example, conclude that whilst related variety is positively related to local employment growth in Holland, this is not the case for unrelated variety. FORNI and PABA (2001) also find that the existence of related industries is important for local growth, whilst FELDMAN and AUDRETSCH (1999) show that the existence of science-based complementary industries stimulates local innovative activity.

Finally, it is worth noting that many studies include population density as an explanatory variable, typically to proxy for urbanisation economies. Again, disaggregated studies find important differences across sectors. However, there is relatively consistent evidence of a negative impact of density on growth in manufacturing from the recent studies by COMBES (2000), DEIDDA et al (2006) and BLIEN AND SUEDEKUM (2005). The evidence on services is less clear but, generally, suggests a positive or non-significant impact. COMBES (2000) interprets this as evidence that congestion effects outweigh any positive spillover effects in manufacturing. This may arise from increased costs for manufacturing products that need to be transported to geographically diverse markets.

It is clear from this brief review of the empirical evidence that there remain many unresolved issues concerning the impact of externalities on local growth. Given that theoretical considerations and the limited existing evidence suggest that spillovers may 
differ across sectors, the most promising avenue for further research would seem to involve pursuing sector level studies. The remainder of this paper presents an empirical study that takes this approach and also considers related and unrelated diversity, crossboundary spillovers and region-specific effects.

\section{THEORETICAL MODEL}

The theoretical framework underlying the empirical analysis of this paper is a version of the commonly used GLAESER et al (1992) model. This approach is based on a simple model of production incorporating a single labour input, a simplification which reflects the lack of data on local capital inputs which typically limits most empirical studies. Suppose that a firm has a production function $A_{t} f\left(l_{t}\right)$, where $A_{t}$ represents technology at time $t$ measured nominally and $l_{t}$ represents labour input. Profit maximization yields the standard condition $A_{t} f^{\prime}\left(l_{t}\right)=w_{t}$ where $w_{t}$ is the wage rate. Taking logs, this can be written in terms of growth rates as:

$$
\log \left(\frac{A_{t+1}}{A_{t}}\right)=\log \left(\frac{w_{t+1}}{w_{t}}\right)-\log \left(\frac{f^{\prime}\left(l_{t+1}\right)}{f^{\prime}\left(l_{t}\right)}\right)
$$


The growth rate of technology is assumed to be the sum of the growth of national and local technology. The growth of national technology reflects changes in product prices and nationwide sectoral technology shifts, whilst local technological growth is assumed to be exogenous to the firm but related to local technological externalities and competitive effects. Thus:

$\log \left(\frac{A_{\text {local }, t+1}}{A_{\text {local }, t}}\right)=g\left(\begin{array}{l}\text { MAR externalities, Jacobs externalities, } \\ \text { Urbanisation economies, Local competition }\end{array}\right)$

Setting $f(l)=l^{1-\alpha}(0<\alpha<1)$ yields:

$\alpha \log \left(\frac{l_{t+1}}{l_{t}}\right)=-\log \left(\frac{w_{t+1}}{w_{t}}\right)+\log \left(\frac{A_{\text {national }, t+1}}{A_{\text {national }, t}}\right)+g($.

If it is assumed that wage growth and the growth of national technology do not vary across regions, then (3) implies that employment growth can be explained by the measures of externalities and competitive effects contained in $\mathrm{g}($.$) . (Initial empirical$ models included average earnings to reflect wage differences across sub-regions but the results were almost invariably insignificant and are not presented in the paper). 


\section{DATA}

Employment data for sub-regions of Great Britain at the 2-digit industry level were obtained from the UK's National On-line Manpower Information System (NOMIS) utilising the 1992 SIC classification scheme and covering the period 1995-2002. It is difficult to examine longer term trends due to the changes to the system of collecting employment data from 1998 onwards. Data from 1995 to 1997 have been rescaled to be consistent with the new system but earlier data reflect the previous system (PARTINGTON, 2001). Data were collected for 203 areas at the local authority, county and unitary authority level. These areas are administrative units and vary from large, densely populated urban regions to smaller, rural sub-regions. Inevitably, this implies that there may be spillovers across areas which have strong economic connections and, consequently it is important to examine spatial autocorrelation.

The 2-digit classification scheme identifies 60 separate sectors although three have zero employment and the data on agriculture are incomplete. The sectors differ considerably in size varying from a few hundred employees to two and a half million. For many of the smaller sectors, sub-regional employment is very small, implying that small changes in employment can give rise to substantial changes in growth rates. Consequently, it was decided to concentrate on the largest 23 sectors, which were each responsible for over $1 \%$ of GB employment in 1995. The basic details of the sample industries are presented in Table 1. The first column classifies the sector into one of the four broad classes identified in VAN OORT (2007) - namely industry (manufacturing, construction and 
telecommunications), distributive services, personal services (mainly sold to consumers) and business services. Such a classification is useful in examining the extent to which broader patterns can be identified in the sector results. Individual sectors vary in size from retail, which accounts for over $10 \%$ of GB employment to manufacturing of rubber and plastics goods accounting for barely $1 \%$ of employment. There are also variations in growth patterns, with manufacturing sectors generally exhibiting falling employment, whilst services typically exhibit growth.

Table 1 inserted approximately here

The dependent variable, employment growth, is defined as the change in the log of employment in a sector in a particular area over the period 1995-2002. This time period is one of positive economic growth and stable levels of diversity and, consequently, the impact of diversity can be examined in the absence of major changes in economic structure (BISHOP AND GRIPAIOS, 2007). However, it is important to recognise that the relationship between diversity and growth may change in more turbulent periods. For example, if industrial structure is changing rapidly, as often occurs during an economic downturn, particular sectors may experience rapid employment change primarily as a consequence of these system-wide factors. This may disrupt the relationship between diversity and growth within sectors affected by such changes.

\footnotetext{
All explanatory variables are measured in 1995 and are in log form (apart from a regional dummy). Sector specialisation is measured by a location quotient, defined as the 
proportion of local employment accounted for by a sector in a specific locality divided by the proportion of employment accounted for by the sector nationally. Whilst this is consistent with the approach adopted in most studies, there are some limitations in using the location quotient as a measure of MAR externalities. A high degree of specialisation may, for example, reflect the dominance of large scale production plants rather than the scope for significant within sector-spillovers. Moreover, the measure purely concentrates upon labour specialisation, neglecting variations in other inputs such as capital.

Unrelated variety is measured by the commonly used entropy measure which can be defined as:

$$
E=\sum_{i=1}^{n} S_{i} \ln \left(\frac{1}{S_{i}}\right)
$$

$s_{i}$ is the share of the $i$ th 2-digit Standard Industrial Classification (SIC) category in a region's total employment and there are $n$ different 2-digit categories. $E$ varies from zero if all employment is concentrated in one sector to $\ln (n)$ if employment is spread evenly across all sectors.

It is possible to derive a measure of related variety by computing an entropy measure at, the 4-digit level for the economy as a whole and decomposing this into related and 
unrelated components (see e.g. FRENKEN 2007). However, economy-wide related diversity is not the key issue for sector analysis; rather it is relatedness specific to the individual sector under consideration. In order to measure this type of relatedness, an entropy measure was calculated at the 4-digit level within every 2-dgit sector. This method is consistent with FRENKEN et al's (2007) approach but applies it at the sector level. It is important to recognise that both entropy measures, in common with many similar measures, are reliant upon the validity of SIC codes as a mechanism through which to capture related and unrelated variety. However, classification of establishments to SIC codes is primarily done on the basis of product relatedness and neglects other aspects of relatedness such as technological similarities and knowledge transfers. SIC codes are hence an imperfect measure of variety but capture one important dimension and have the advantage of being readily available.

Growth regressions typically include a variable representing competitive effects. However, there are contrary views as to the theoretical impact of competition on growth (VAN STEL AND NIEUWENHUIJSEN, 2004). One view is that competition stimulates firms to innovate and thereby generates growth, whilst another approach argues that growth is promoted by market power as firms can more easily internalise the benefits of new developments (VAN OORT, 2007). Whichever view one takes, measuring market structure at the local level is a problematic exercise as local concentration ratios or similar measures are not available. Consequently, the paper utilises a measure based on size band data defined as the proportion of establishments in the sector with 10 or fewer employees relative to the proportion in this category in GB as a whole. Whilst such a 
measure might plausibly measure competition, it might also be a proxy for the typical size of local business units and hence reflect scale factors. Hence, care needs to be taken in the interpretation of this variable.

Population density, defined as population per square kilometre, was used as a proxy for urbanisation economies (DEWHURST AND MCCANN, 1999). Finally, the possibility of spatial heterogeneity was also included by using dummies for different types of regions. Recent studies by by ROBERTS (2004) and BISHOP AND GRIPAIOS (2007) reveal some evidence of a north-south divide in patterns of GDP growth and, consequently, a simple north-south divide dummy variable (south $=1$ ) was utilized, with the south defined as the South East, South West and Eastern regions. Other spatial regime variables (e.g. different definitions of the north-south divide) were investigated but generally performed poorly and are not presented in the results.

\section{METHOD AND RESULTS}

The sector growth models were initially estimated using standard OLS. However, specification tests revealed evidence of heteroscedasticity which was only partly relieved by $\log$ transformations of the variables. As the precise form of the heteroscedasticity was not obvious (as required for weighted least squares), heteroscedastic-consistent robust standard errors were estimated using the jacknife method and all the reported standard errors for the OLS models are of this type. 
An additional potential source of specification problems is spatial autocorrelation arising from a lack of independence amongst observations (ANSELIN and REY, 1991). This may reflect either true interaction of variables across spatial units (lag dependence) arising, for example, through spillover effects, or measurement problems (error dependence) reflecting the fact that spatial units do not reflect the correct spatial extent of relevant variables. These issues were examined by conducting Moran tests for spatial autocorrelation and LM tests to distinguish between error and lag specifications. The Moran statistic suggested the possible existence of spatial autocorrelation in eleven sectors, although in three cases (sectors $45,50,54)$ subsequent investigation revealed non-significant spatial coefficients and hence the OLS model was retained. In the remaining eight cases, the error specification was preferred in six cases and the lag specification in two cases suggesting that measurement related issues are of particular significance. For these eight sectors, maximum likelihood models incorporating either lag or error dependence were estimated with spatial dependence represented by a contiguity based binary weight matrix. Within the matrix, areas were coded as 1 if they shared a geographical boundary and zero otherwise. (This simple order of contiguity was preferable to second order contiguity which did not significantly alter the conclusions or improve the power of the models). The spatial models either eliminated or significantly reduced heteroscedasticity but only resulted in minor changes in the pattern of significant variables compared to the OLS estimates.

The results of the sector models are presented in Tables 2 - 4. Most of the OLS models (with the exception of sector 65) have reasonable levels of fit and are comparable to other 
studies of this type. The $\mathrm{R}^{2}$ 's for the spatial models are pseudo- $\mathrm{R}^{2}$, $s$ and hence not directly comparable to those of the OLS models. However, in all cases, the log-likelihood measure of fit for the spatial models is an improvement over the OLS alternative and the spatial coefficient (representing either a spatial lag or error) is significant at the $10 \%$ level. Inspection of the correlation matrix and other indicators revealed no serious evidence of multi-collinearity.

Tables 2, 3 and 4 inserted approximately here

There is little evidence of inconsistencies across sectors in terms of the signs of the significant variables apart from the north-south and density variables. This suggests that differences across sectors are primarily associated with the magnitude or presence/absence of an effect rather than its direction. The most consistent result is the significant, negative impact of specialisation on employment growth which is observed in all but one of the equations. This confirms the broad results of the recent sector studies by COMBES (2000) and DEIDDA et al (2006). However, it is important to recognise that these results (in common with those of similar studies) cannot be interpreted as definitive evidence against the presence of MAR externalities. It is possible that specialisation may be beneficial but primarily result in improvements in productivity which displace labour due to demand constraints on expanding output.

The competition (or scale effect) variable is significantly positive in 16 of the 23 sectors, implying that a large number of small firms in a sector is generally conducive to 
employment growth. Interestingly, two of the three service sectors for which the variable is insignificant (75 and 80) are public sector dominated sectors. This is understandable, as one might expect competitive effects to be less important when a sector is characterised by public ownership. The positive impact of local competition on most manufacturing industries is more surprising as it might be expected that such industries would be more affected by national or international competition. The positive sign may possibly reflect a product life-cycle effect, with many small, young firms able to generate rapid employment growth in early years, whilst this is more difficult for larger firms operating at later stages of the life-cycle. It is also interesting to note that the consistent results concerning competition differ markedly from those found in previous studies. DEIDDA et al (2006), for example, find the impact of competition is variable and generally insignificant whilst COMBES (2000) finds competition to have a negative impact where significant. These differences may reflect different measures of competition, countries and time periods and further research is needed on the impact of the variable. However, the consistent and significant results of the variable used in the present study suggest that this type of measure may have some merit.

Unrelated variety is insignificant in 15 sectors, which is consistent with FRENKEN et $a$ l's (2004) argument that unrelated variety is unlikely to generate employment growth. However, there are eight sectors for which a significantly positive effect is observed which suggests that sectors are not homogenous. Interestingly, some broad differences between manufacturing and services can be observed with five out of the eight industrial sectors showing a positive impact in contrast to only three of the fifteen service sectors. 
These results are more consistent with the results of DEIDDA et al (2006) than COMBES (2000) who finds that unrelated diversity generally has a negative or significant impact on industry. Related variety is insignificant in all but four sectors and the sign is inconsistent; it has a positive impact in three sectors and a negative impact in one. Clearly, this fails to support the contention that related variety generally stimulates employment growth. Taken together, these results suggest that the distinction between unrelated variety and related variety is important and that differences across sectors are of some significance.

The density variable performs poorly being significant in only seven equations and with an inconsistent sign. This suggests that either urbanisation economies are not of general significance or are offset by diseconomies, possibly arising from congestion. Again, the results are more consistent with the pattern found in DEIDDA et al (2006) than COMBES (2000). The north-south divide dummy is significant in nine equations. For manufacturing industries, the sign is negative when significant implying better performance in the north than the south. In other sectors the sign is generally positive, suggesting the reverse. This implies that there are some broad spatial effects at work in some industries but the simple notion of a north-south divide masks significant sector differences. Spatial autocorrelation is most apparent in business services and involves an error specification, suggesting that interdependencies are related to measurement errors reflecting the artificial nature of administrative boundaries in delineating local markets for these services. 


\section{CONCLUSION}

The analysis presented in this paper highlights a number of issues that are of significance for future research concerning local growth and the development of policies to promote regional development. The consistently negative impact of specialisation suggests that encouraging local specialisation is not a policy option that is likely to yield substantial short-term gains in terms of employment creation. However, it is possible that there may be long term benefits accruing from productivity improvements associated with specialisation which are not apparent from employment regressions. This raises an interesting dilemma for policy makers, who are often concerned with employment creation as a policy objective. From a theoretical point of view, it also emphasises the limited nature of the recommendations that can be made on the basis of the sign of the specialisation coefficient in employment regressions. Unfortunately, in the absence of a substantial improvement in the availability of sub-regional data, it is inevitable that much future empirical work will continue to use this approach.

As far as diversity is concerned, the results suggest considerable heterogeneity across sectors with just under half of the sectors examined benefiting from one of the two forms of diversity. In contrast to the hypotheses in the literature, unrelated variety has a wider impact than related variety, suggesting that a sector approach might question the results of the more aggregated literature. The heterogeneity of the impact of diversity is perhaps not surprising, given that the opportunity to benefit from spillovers is likely to depend critically on the specific technologies, customers and knowledge relevant to a particular 
sector. Indeed, it seems sensible to conclude that diversity is a complex and heterogeneous phenomenon, rather than looking for a simple relationship between growth and diversity that operates across all sectors. This implies that policy should be concerned with understanding and developing specific opportunities for spillovers, rather than simply promoting the general idea of diversity. Of course, diversity may also yield other benefits, such as improving stability, which are not directly examined in this paper.

One interesting question that arises from the study is where to draw the line between diversity and specialisation. Relatedness might, for example, be regarded as evidence of the existence of a set of sectors which constitute a cluster rather than an indication of diversity. Indeed, making a simple distinction between specialisation and diversity masks the fact that the degree of commonality between sectors varies along a continuum. Thus, future research might usefully develop more sophisticated measures of the degree of commonality across sectors. One possible method is through the use of input-output analysis to examine demand and supply linkages (e.g. FORNI AND PABA, 2001), although this approach will inevitably be constrained by the limited availability of local data.

Another issue raised by the paper concerns the existence of wider spatial effects across economic boundaries. The diverse results concerning spatial autocorrelation suggest that the spatial extent of markets may differ across industrial sectors. The administrative boundaries for which data are collected may be reasonable approximations for some sectors but inappropriate in other cases. Thus, even attempting to construct boundaries 
(such as functional urban areas) to represent more economically coherent regions, may not fully eliminate spatial autocorrelation. From a policy perspective, this implies that policy makers need to be aware of differences in the spatial extent of markets across which they define clusters and implement policy.

Finally, the generally positive impact of the share of small firms on employment growth suggests that encouraging local competition may be an appropriate policy option. Indeed, the generality of this effect implies that this may be an easier policy to implement than polices stimulating the development of a particular cluster, which requires detailed knowledge of spillovers, linkages and the spatial markets appropriate to a specific sector. Given the difficulties of such an exercise, policy might be best centred on creating the conditions appropriate to enhancing competitiveness across all sectors rather than attempting to micro-manage specific sectors. Future research into local growth should also perhaps place more attention on the role of competition and firm size, rather than the current emphasis on diversity and specialisation. 


\title{
REFERENCES
}

\begin{abstract}
ANSELIN, L. and REY, S. (1991) The performance of tests for spatial dependence in linear regression models, Geographical Analysis, 23:110-131.
\end{abstract}

BISHOP, P. and GRIPAIOS, P. (2007) Explaining spatial patterns of industrial diversity: an analysis of sub-regions in Great Britain, Urban Studies, 44.9, 1739-1757.

BLIEN, U. and SUEDEKUM, J. (2005) Local economic structure and industry development in Germany (1993-2001), IAB Discussion paper, N0. 1/2005, German Federal Employment Agency.

BRUCHE, G, (2000). Corporate Strategy, Relatedness and Diversification, Business Institute Berlin, Working Paper, 13, Berlin.

BRYAN, J., JONES, C. and MUNDAY, M. (2005) Investigating the potential of key sectors using multi-sectoral qualitative analysis: a Welsh case study, Environment and Planning C, 23: 633-656.

CINGANO, F. and F. SCHIVARDI (2002) Identifying the sources of local productivity growth, Journal of the European Economic Association, 2: 720-742.

COMBES, P-PH. (2000) Economic Structure and Local Growth: France 1984-93, Journal of Urban Economics, 47, 329-355. 
COMBES, P.-P., T. MAGNAC, and J.-M. ROBIN (2004) The dynamics of local employment in France, Institute for the Study of Labor, Discussion paper No. 1061, Bonn.

CUMBERS, A. and MACKINNON, D. (2004) Introduction: Clusters in Urban and Regional Development, Urban Studies, 5/6: 959-969.

DECKLE, R. (2002) Industrial Concentration and Regional Growth: evidence from the prefectures, The Review of Economics and Statistics, 84: 310-315.

DEIDDA. S., PACI, R. and USAI, S. (2006) Spatial externalities and local economic growth, CRENOS, Contribiti Di Ricerca, 02/06.

ESSLETZBICHLER, J. (2002) Diversity, growth and stability: employment evolutions in US labour market regions, paper prepared for the $4^{\text {th }}$ European meeting of Applied Evolutionary economics, Utrecht, May 19-21.

FORNI, M. and PABA, S. (2001) Knowledge Spillovers and the Growth of Local Industries, CEPR discussion paper, no 2934.

FRENKEN, K., VAN OORT, F.G., AND VERBURG, T. (2007) Related Variety, Unrelated Variety and Regional Economic Growth, Regional Studies, 41.5, 685-697. 
GLAESER, E., H. KALLAL, J. SHEINKMAN, and A. SCHLEIFER (1992) Growth in cities, Journal of Political Economy, 100,1126-1152.

\begin{abstract}
HENDERSON, V., A. KUNCORO, and M. TURNER (1995) Industrial development in cities, Journal of Political Economy, 103, 1067-1152.
\end{abstract}

JACOBS, J. (1969) The economy of cities, New York, Vintage.

KRUGMAN, P. and A. J. VENABLES (1995) Globalization and the inequality of nations, Quarterly Journal of Economics, 110, 857-880.

DEWHURST, J.H. LL. and MCCANN, P. (1999) Specialisation and regional size, paper presented to the ESRC Urban and Regional Economics Seminar Group meeting, Carlisle.

MARSHALL, A. (1890) Principles of Economics, London, Macmillan.

PACI, R and S. USAI (2002) Externalities and local economic growth in manufacturing industries, CRENOS working paper no 01/13.

PARTINGTON, J. (2001) The launch of the Annual Business Inquiry, Labour Market Trends, May, 1-6. 
PORTER, M. (1998) On Competition. Boston, Harvard University Press.

PORTER, M. (2000) Locations, clusters and company strategy in Clark, G. L., Feldman, M. and Gertler, M. eds. The Oxford Handbook of Economic Geography, OUP, Oxford, pp. 253-74.

ROMER, P.M. (1986) Increasing Returns and Long-Run Growth, The Journal of Political Economy, 94.5. 1002-1037

ROBERTS, M. (2004) The growth performance of the GB counties; some new empirical evidence for 1997-93, Regional Studies, 38, 149-165.

SHEARMUR, R. and POLESE, M. (2005) Diversity and employment growth in Canada, 1971-2001: can diversification policies succeed? The Canadian Geographer, 49, No. 3, 272-290.

VAN OORT, F.G. (2007) Spatial and sectoral composition effects of agglomeration economies in the Netherlands, Papers in Regional Science, 86. 1, 5-30

VAN STEL, A.J. and NIEUWENHUIJESEN, H.R. (2004) Knowledge spillovers and economic growth: an analysis using data of Dutch regions in the period 1989-1995, Regional Studies, 393-407. 
VAN SOEST, D.P., GERKING, S. \& VAN OORT, F.G. (2006). Spatial Impacts of Agglomeration Externalities, Journal of Regional Science, 46(5), pp 881-899.

1

2

4

5

6

7

8

9

10

11

12

13

14

15

16

17

18

19

20

21

22

23

24

25

26

27

28

29

30

31

32

33

34

35

36

37

38

39

40

41

42

43

44

45

46

47

48

49

50

51

52

53

54

55

56

57

58

59

60 
Table 1: Employment in GB 2-digit sectors 1995

\begin{tabular}{|c|c|c|c|c|}
\hline & $\begin{array}{l}\text { Broad* } \\
\text { Sector }\end{array}$ & $\begin{array}{c}\text { Employment } \\
1995\end{array}$ & $\begin{array}{c}\% \text { of GB } \\
1995\end{array}$ & $\begin{array}{l}\text { \% growth } \\
1995-02\end{array}$ \\
\hline 15 : Manuf food products and beverages & IND & 453426 & 2.02 & -0.03 \\
\hline 22 : Publishing,printing,repro recorded media & IND & 340491 & 1.51 & 0.00 \\
\hline 24 : Manuf chemicals and chemical products & IND & 249840 & 1.11 & -0.08 \\
\hline 25 : Manuf rubber and plastic goods & IND & 229614 & 1.02 & -0.08 \\
\hline 28 : Manuf fabricated metal products, etc & IND & 419994 & 1.87 & -0.16 \\
\hline 29 : Manuf machinery and equipment nec & IND & 383822 & 1.71 & -0.21 \\
\hline 45 : Construction & IND & 901104 & 4.01 & 0.29 \\
\hline 50 : Sale,maintenance/repair motor vehicles & DIS & 563970 & 2.51 & -0.02 \\
\hline 51: Wholesale trade/commission trade, etc & DIS & 1029524 & 4.58 & 0.09 \\
\hline 52 : Retail trade, except of motor vehicles & PER & 2344116 & 10.42 & 0.25 \\
\hline 55 : Hotels and restaurants & PER & 1417072 & 6.3 & 0.21 \\
\hline 60 : Land transport; transport via pipelines & DID & 501746 & 2.23 & -0.01 \\
\hline 63 : Supporting/auxilliary transport,etc & DIS & 315124 & 1.4 & 0.3 \\
\hline 64 : Post and telecommunications & IND & 442685 & 1.97 & 0.24 \\
\hline 65 : Financial intermediation, etc & BUS & 624932 & 2.78 & 0.01 \\
\hline 70 : Real estate activities & BUS & 298057 & 1.33 & 0.25 \\
\hline 72 : Computing and related activities & BUS & 236458 & 1.05 & 1.05 \\
\hline 74 : Other business activities & BUS & 2282713 & 10.15 & 0.23 \\
\hline 75 : Public admin/defence; compulsory SS & PER & 1345005 & 5.98 & -0.01 \\
\hline 80 : Education & PER & 1676554 & 7.45 & 0.33 \\
\hline 85 : Health and social work & PER & 2500681 & 11.12 & 0.12 \\
\hline 92 : Recreational, cultural and sporting & PER & 563206 & 2.5 & 0.26 \\
\hline 93 : Other service activities & PER & 241127 & 1.07 & 0.33 \\
\hline
\end{tabular}

*IND = industry; DIS = distribution; PER = personal services $;$ BUS = business services. 
Table 2: Industry growth models

\begin{tabular}{|c|c|c|c|c|c|c|c|c|}
\hline & & & & Sector & & & & \\
\hline & 15 & 22 & 24 & 25 & 28 & 29 & 45 & 64 \\
\hline Constant & $\begin{array}{l}-3.062 * * \\
(0.699)\end{array}$ & $\begin{array}{l}-0.038 \\
(0.524)\end{array}$ & $\begin{array}{l}-3.005 \\
(4.919)\end{array}$ & $\begin{array}{l}-9.836^{* *} \\
(3.538)\end{array}$ & $\begin{array}{l}-2.808 * * \\
(0.997)\end{array}$ & $\begin{array}{l}-4.375^{* *} \\
(2.462)\end{array}$ & $\begin{array}{l}-1.220^{*} \\
(0.731)\end{array}$ & $\begin{array}{l}-1.367 * * \\
(0.660)\end{array}$ \\
\hline $\begin{array}{l}\text { Regional } \\
\text { Dummy }\end{array}$ & $\begin{array}{l}-0.224 * * \\
(0.084)\end{array}$ & $\begin{array}{l}-0.091 \\
(0.064)\end{array}$ & $\begin{array}{l}0.049 \\
(0.135)\end{array}$ & $\begin{array}{l}-0.238^{*} \\
(0.123)\end{array}$ & $\begin{array}{l}-0.201 * * \\
(0.089)\end{array}$ & $\begin{array}{l}-0.021 \\
(0.084)\end{array}$ & $\begin{array}{l}0.061 \\
(0.051)\end{array}$ & $\begin{array}{l}0.055 \\
(0.073)\end{array}$ \\
\hline $\begin{array}{l}\text { Unrelated } \\
\text { Variety }\end{array}$ & $\begin{array}{l}2.864 * * \\
(0.602)\end{array}$ & $\begin{array}{l}0.143 \\
(0.422)\end{array}$ & $\begin{array}{l}2.512 \\
(3.594)\end{array}$ & $\begin{array}{l}8.816^{* * *} \\
(3.073)\end{array}$ & $\begin{array}{l}2.517 * * \\
(0.852)\end{array}$ & $\begin{array}{l}3.618^{*} \\
(2.133)\end{array}$ & $\begin{array}{l}1.035 \\
(0.632)\end{array}$ & $\begin{array}{l}0.939 * \\
(0.545)\end{array}$ \\
\hline Density & $\begin{array}{l}-0.024 \\
(0.025)\end{array}$ & $\begin{array}{l}-0.014 \\
(0.0181)\end{array}$ & $\begin{array}{l}-0.029 \\
(0.093)\end{array}$ & $\begin{array}{l}-0.051 \\
(0.056)\end{array}$ & $\begin{array}{l}-0.028 \\
(0.023)\end{array}$ & $\begin{array}{l}-0.010 \\
(0.028)\end{array}$ & $\begin{array}{l}0.026^{*} \\
(0.014)\end{array}$ & $\begin{array}{l}0.076^{* *} \\
(0.027)\end{array}$ \\
\hline $\begin{array}{l}\text { Location } \\
\text { Quotient }\end{array}$ & $\begin{array}{l}-0.368^{* *} \\
(0.065)\end{array}$ & $\begin{array}{l}-0.276 * * \\
(0.079)\end{array}$ & $\begin{array}{l}-0.453^{* *} \\
(0.171)\end{array}$ & $\begin{array}{l}-0.671 * * \\
(0.179)\end{array}$ & $\begin{array}{l}-0.520^{* *} \\
(0.062)\end{array}$ & $\begin{array}{l}-0.387 * * \\
(0.083)\end{array}$ & $\begin{array}{l}-0.418 * * \\
(0.062)\end{array}$ & $\begin{array}{l}-0.532 * * \\
(0.115)\end{array}$ \\
\hline Competition & $\begin{array}{l}0.328^{* *} \\
(0.012)\end{array}$ & $\begin{array}{l}0.412 * * \\
(0.105)\end{array}$ & $\begin{array}{l}0.467 \\
(0.029)\end{array}$ & $\begin{array}{l}-0.150 \\
(0.154)\end{array}$ & $\begin{array}{l}0.567 * * \\
(0.097)\end{array}$ & $\begin{array}{l}0.384 * * \\
(0.145)\end{array}$ & $\begin{array}{l}0.343 * * \\
(0.100)\end{array}$ & $\begin{array}{l}0.157 \\
(0.139)\end{array}$ \\
\hline $\begin{array}{l}\text { Related } \\
\text { Variety }\end{array}$ & $\begin{array}{l}-0.056 \\
(0.084)\end{array}$ & $\begin{array}{l}-0.021 \\
(0.083)\end{array}$ & $\begin{array}{l}0.179 \\
(0.157)\end{array}$ & $\begin{array}{l}0.124 \\
(0.077)\end{array}$ & $\begin{array}{l}-0.059 \\
(0.037)\end{array}$ & $\begin{array}{l}0.072 \\
(0.141)\end{array}$ & $\begin{array}{l}0.175 \\
(0.123)\end{array}$ & $\begin{array}{l}0.336^{* *} \\
(0.101)\end{array}$ \\
\hline $\begin{array}{l}\text { Spatial } \\
\text { Coefficient }\end{array}$ & & & & & $\begin{array}{l}0.206^{* * *} \\
(0.091)\end{array}$ & & & \\
\hline $\mathrm{R}^{2(A d j)}$ & 0.256 & 0.158 & 0.343 & 0.526 & & 0.251 & 0.362 & 0.293 \\
\hline Psuedo- $\mathrm{R}^{2}$ & & & & & 0.307 & & & \\
\hline $\begin{array}{l}\text { Moran } \\
\text { P-value }\end{array}$ & $\begin{array}{l}0.730 \\
(0.465)\end{array}$ & $\begin{array}{l}0.977 \\
(0.329)\end{array}$ & $\begin{array}{l}1.369 \\
(0.171)\end{array}$ & $\begin{array}{l}0.687 \\
(0.492)\end{array}$ & $\begin{array}{l}2.594 * * \\
(0.009)\end{array}$ & $\begin{array}{l}0.171 \\
(0.864)\end{array}$ & $\begin{array}{l}1.656 * \\
(0.098)\end{array}$ & $\begin{array}{l}1.833 * \\
(0.067)\end{array}$ \\
\hline $\begin{array}{l}\text { LM(lag) } \\
\text { P-value }\end{array}$ & & & & & $\begin{array}{l}1.738 \\
(0.187)\end{array}$ & & & \\
\hline $\begin{array}{l}\text { LM(error) } \\
\text { P-value }\end{array}$ & & & & & $\begin{array}{l}4.389 * * \\
(0.036)\end{array}$ & & & \\
\hline LLikelihood & -150.6 & -71.4 & -312.1 & -262.5 & -118.5 & -162.5 & -11.7 & -123.8 \\
\hline & OLS & OLS & OLS & OLS & $\begin{array}{l}\text { Spatial } \\
\text { Error }\end{array}$ & OLS & OLS & OLS \\
\hline
\end{tabular}

Notes: $* *(*)$ indicates significance at the 5\% (10\%) level respectively; figures in brackets after regression coefficients are heteroscedastic consistent standard errors ; $\mathrm{N}=203$ in all cases.

http://mc.manuscriptcentral.com/cres Email: regional.studies@newcastle.ac.uk 
Table 3: Growth models for distribution (50-63) and business services (65-74)

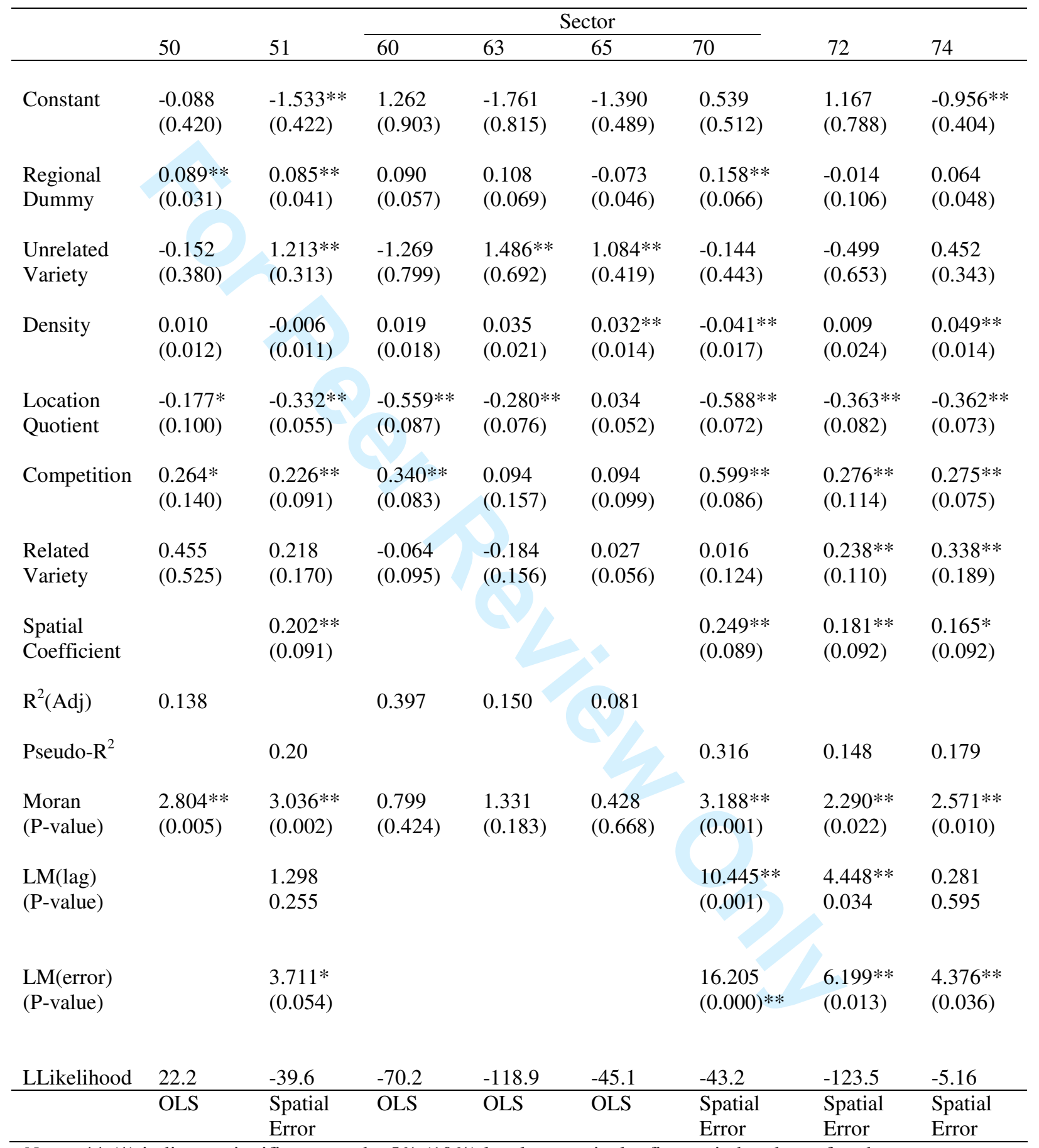

Notes: $* *(*)$ indicates significance at the 5\% (10\%) level respectively; figures in brackets after the regression coefficients are heteroscedastic consistent standard errors; $\mathrm{N}=203$ in all cases. 
Table 4: Growth models for personal services

\begin{tabular}{|c|c|c|c|c|c|c|c|}
\hline & & & & Sect & & & \\
\hline & 52 & 55 & 75 & 80 & 85 & 92 & 93 \\
\hline Constant & $\begin{array}{l}0.666 * * \\
(0.262)\end{array}$ & $\begin{array}{l}0.333 \\
(0.322)\end{array}$ & $\begin{array}{l}0.883 \\
(0.637)\end{array}$ & $\begin{array}{l}0.041 \\
(0.482)\end{array}$ & $\begin{array}{l}0.532 \\
(1.419)\end{array}$ & $\begin{array}{l}0.176 \\
(0.513)\end{array}$ & $\begin{array}{l}-0.256 \\
(0.383)\end{array}$ \\
\hline $\begin{array}{l}\text { Regional } \\
\text { Dummy }\end{array}$ & $\begin{array}{l}0.083 * * \\
(0.032)\end{array}$ & $\begin{array}{l}0.117 * * \\
(0.033)\end{array}$ & $\begin{array}{l}-0.128 * * \\
(0.042)\end{array}$ & $\begin{array}{l}0.009 \\
(0.026)\end{array}$ & $\begin{array}{l}-0.003 \\
(0.051)\end{array}$ & $\begin{array}{l}0.044 \\
(0.039)\end{array}$ & $\begin{array}{l}0.009 \\
(0.043)\end{array}$ \\
\hline $\begin{array}{l}\text { Unrelated } \\
\text { Variety }\end{array}$ & $\begin{array}{l}-0.135 \\
(0.193)\end{array}$ & $\begin{array}{l}-0.175 \\
(0.268)\end{array}$ & $\begin{array}{l}-0.639 \\
(0.543)\end{array}$ & $\begin{array}{l}0.243 \\
(0.401)\end{array}$ & $\begin{array}{l}-0.162 \\
(1.266)\end{array}$ & $\begin{array}{l}0.051 \\
(0.435)\end{array}$ & $\begin{array}{l}0.381 \\
(0.331)\end{array}$ \\
\hline Density & $\begin{array}{l}-0.024 * * \\
(0.007)\end{array}$ & $\begin{array}{l}-0.005 \\
(0.011)\end{array}$ & $\begin{array}{l}-0.005 \\
(0.014)\end{array}$ & $\begin{array}{l}-0.004 \\
(0.010)\end{array}$ & $\begin{array}{l}-0.024 * * \\
(0.010)\end{array}$ & $\begin{array}{l}0.000 \\
(0.010)\end{array}$ & $\begin{array}{l}-0.002 \\
(0.011)\end{array}$ \\
\hline $\begin{array}{l}\text { Location } \\
\text { Quotient }\end{array}$ & $\begin{array}{l}-0.338^{* *} \\
(0.045)\end{array}$ & $\begin{array}{l}-0.323 * * \\
(0.052)\end{array}$ & $\begin{array}{l}-0.430 * * \\
(0.057)\end{array}$ & $\begin{array}{l}-0.265^{* *} \\
(0.067)\end{array}$ & $\begin{array}{l}-0.422 * * \\
(0.098)\end{array}$ & $\begin{array}{l}-0.478^{* *} \\
(0.080)\end{array}$ & $\begin{array}{l}-0.480 * * \\
(0.071)\end{array}$ \\
\hline Competition & $\begin{array}{l}0.235^{* *} \\
(0.065)\end{array}$ & $\begin{array}{l}0.151^{* *} \\
(0.055)\end{array}$ & $\begin{array}{l}0.061 \\
(0.043)\end{array}$ & $\begin{array}{l}-0.008 \\
(0.048)\end{array}$ & $\begin{array}{l}0.314 * * \\
(0.157)\end{array}$ & $\begin{array}{l}0.322 * * \\
(0.076)\end{array}$ & $\begin{array}{l}0.267 * * \\
(0.102)\end{array}$ \\
\hline $\begin{array}{l}\text { Related } \\
\text { Variety }\end{array}$ & $\begin{array}{l}-0.201 \\
(0.154)\end{array}$ & $\begin{array}{l}-0.138 \\
(0.124)\end{array}$ & $\begin{array}{l}-0.185 * * \\
(0.087)\end{array}$ & $\begin{array}{l}0.028 \\
(0.087)\end{array}$ & $\begin{array}{l}-0.131 \\
(0.148)\end{array}$ & $\begin{array}{l}-0.072 \\
(0.210)\end{array}$ & $\begin{array}{l}0.018 \\
(0.117)\end{array}$ \\
\hline $\begin{array}{l}\text { Spatial } \\
\text { Coefficient }\end{array}$ & $\begin{array}{l}0.200 * * \\
(0.091)\end{array}$ & $\begin{array}{l}0.349 * * \\
(0.077)\end{array}$ & & & & & $\begin{array}{l}0.344 * * \\
(0.079)\end{array}$ \\
\hline $\mathrm{R}^{2}$ (Adj) & & & 0.36 & 0.159 & 0.238 & 0.223 & \\
\hline Psuedo- $\mathrm{R}^{2}$ & 0.260 & 0.392 & & & & & 0.370 \\
\hline $\begin{array}{l}\text { Moran } \\
\text { (P-value) }\end{array}$ & $\begin{array}{l}2.845^{* *} \\
(0.004)\end{array}$ & $\begin{array}{l}4.926 * * \\
(0.000)\end{array}$ & $\begin{array}{l}1.433 \\
(0.152)\end{array}$ & $\begin{array}{l}-0.548 \\
(0.584)\end{array}$ & $\begin{array}{l}0.071 \\
(0.943)\end{array}$ & $\begin{array}{l}0.885 \\
(0.376)\end{array}$ & $\begin{array}{l}5.470 * * \\
(0.000)\end{array}$ \\
\hline $\begin{array}{l}\text { LM(lag) } \\
\text { (P-value) }\end{array}$ & $\begin{array}{l}2.133 \\
0.144\end{array}$ & $\begin{array}{l}3.867 * * \\
(0.049)\end{array}$ & & & & & $\begin{array}{l}26.139 * * \\
(0.000)\end{array}$ \\
\hline $\begin{array}{l}\text { LM(error) } \\
\text { (P-value) }\end{array}$ & $\begin{array}{l}4.873^{* *} \\
(0.027)\end{array}$ & $\begin{array}{l}0.019 \\
0.890\end{array}$ & & & & & $\begin{array}{l}0.005 \\
(0.941)\end{array}$ \\
\hline Likelihood & -120.4 & 56.26 & -5.60 & 42.73 & 40.16 & 5.97 & 5.52 \\
\hline & $\begin{array}{l}\text { Spatial } \\
\text { error }\end{array}$ & $\begin{array}{l}\text { Spatial } \\
\text { Lag }\end{array}$ & OLS & OLS & OLS & OLS & Spatial La \\
\hline
\end{tabular}

Notes: ** $(*)$ indicates significance at the 5\% (10\%) level respectively; figures in brackets after regression coefficients are heteroscedastic consistent standard errors; $\mathrm{N}=203$ in all cases. 